\title{
Art and pain in Frida Kahlo*
}

\author{
Arte e dor em Frida Kahlo
}

Rodrigo Siqueira-Batista ${ }^{1,2}$, Plínio Duarte Mendes ${ }^{3}$, Julia de Oliveira Fonseca ${ }^{1}$, Marina de Souza Maciel ${ }^{4}$

${ }^{*}$ Received from the Federal University of Viçosa, Viçosa, MG, Brazil. The article is result of the project "Parallel between health and art: Frida Kahlo's colors", appreciated and approved by the Ethics Committee for Research with Human Beings, UFV (Of. Ref. N 005/2012/CEPH).

DOI 10.5935/1806-0013.20140018

\section{ABSTRACT}

BACKGROUND AND OBJECTIVES: The Mexican painter Frida Kahlo is one of the most important artists of the twentieth century. After being involved in a car accident, remained at home to recover from several injuries, significant event for the dawning of her painting. The aim of this study was to present aspects of the biography and life of Frida, seeking intersections between her artwork and her painful experiences.

CONTENTS: From the appreciation of film and screens selected author - analyzed with the support of the articles obtained in the literature review - held four sections to the presentation of evidence obtained: (1) the 'origins' of Frida (2) first accident, (3) the second accident: Diego Rivera and (4) the Martyrdom of frustrated motherhood.

CONCLUSION: Frida found in art her comfort, transforming her painful and intense trajectory in a work that reflected the meaning of her existence.

Keywords: Chronic pain, Medicine and art, Paintings, Psychological stress.

\section{RESUMO}

JUSTIFICATIVA E OBJETIVOS: A pintora mexicana Frida Kahlo é uma das mais importantes artistas do século XX. Após envolvimento em um acidente automobilístico, permaneceu em repouso para se recuperar das diversas lesóes, evento significativo para o alvorecer de sua pintura. O objetivo deste estudo foi apresentar aspectos da biografia e da arte de Frida, buscando interseçóes entre sua arte e suas experiências de dor.

1. Federal University of Viçosa, Viçosa, MG, Brazil.

2. Federal University of Rio de Janeiro, Rio de Janeiro, RJ, Brazil.

3. Biocor Institute, Belo Horizonte, MG, Brazil.

4. Federal University of Minas Gerais, Belo Horizonte, MG, Brazil.

Submitted in May 31, 2013.

Accepted for publication in May 14, 2014.

Conflict of interests: none.

Correspondence to:

Rodrigo Siqueira-Batista

Universidade Federal de Viçosa

Departamento de Medicina e Enfermagem

Av. Peter Henry Rolfs, s/n. Campus Universitário

36570-000 Viçosa, MG, Brasil.

E-mail: rsiqueirabatista@yahoo.com.br

(C) Sociedade Brasileira para o Estudo da Dor
CONTEÚDO: A partir da apreciação do filme e de telas selecionadas da autora - analisadas com o apoio dos artigos obtidos na revisão da literatura - foram organizadas quatro seçóes para a apresentação dos elementos obtidos: (1) As 'origens' de Frida, (2) $O$ primeiro acidente, (3) O segundo acidente: Diego Rivera e (4) O martírio da maternidade frustrada.

CONCLUSÁO: Frida obteve na arte seu maior conforto, transformando sua trajetória dolorosa e intensa em um fecundo processo de criação, o qual refletiu os sentidos de sua existência.

Descritores: Dor crônica, Estresse psicológico, Medicina na arte, Pinturas.

\section{INTRODUCTION}

Mexican painter Magdalena Carmen Frida Kahlo Calderón is considered one of the most important artists of the $20^{\text {th }}$ Century. Although born in 1907, in the city of Coyoacán, she has changed her birth date to 1910 , to pay homage to the Mexican Revolution, aspect which well expresses her revolutionary spirit. She was the third daughter of Matilde Calderón y Gozález, catholic and of Amerindian and Spanish ancestry, and Guillermo Kahlo, photograph, Jew, descendent of Austro-Hungarian Germans ${ }^{1}$.

Frida's early experiences with suffering are attributed to acute poliomyelitis sequelae, disease which affected her when she was six years old. As consequences she had right lower limb hypotrophy and right foot atrophy, which has caused severe ailment to the future artist for having been nicknamed "Frida wooden leg". As from this, she started to wear slacks - afterward, long and exotic skirts - clothes which, later, have become one of her trademarks ${ }^{2}$. Between 1922 and 1925 she attended the National Preparatory School, aiming at studying medicine, dream that was interrupted when she was 18 years old, after being involved in a severe accident between a trolleycar and a bus, when she suffered several injuries and fractures which have required a long recovery period. This is considered a determinant factor for the dawn of her paintings. The mirror fixed on a canopy which covered the bed allowed Frida to cope with boredom by portraying herself, making the series of self-portraits a significant part of her artwork $^{1}$.

From then on, slowly, Frida would become an internationally recognized artist, in a trajectory colored by different experiences, especially pain (accident sequela) which accompanied her throughout her life and misadventures of her intense passion for the renowned muralist Diego Rivera, 21 years older, with whom she had a long and turbulent relationship, full of betray- 
als. About the love she had for Diego, the painter reveals having been her worst suffering ${ }^{3}$.

Relations between art and suffering - in Frida Kahlo - are, in this perspective, inextricable. In fact, this manuscript intends to go through snapshots of Frida Kahlo's history and art - especially focusing on intersections of the latter with pain experiences - reflecting about major painter's artworks. For such, the literature was reviewed with defined search strategy - LILACS, Scielo and Pubmed - all belonging to Health Sciences Descriptors (DeCS: http://decs.bvs. $\mathrm{br} /$ ) - in addition to the term Frida Kahlo. Limit date for the search was February 28, 2014. Additionally, books related to the artist were used as integral part of the literature survey, in addition to the appreciation of paintings obtained in the portal www.fridakahlofans. com. Table 1 shows the total of quotes found $(n=45)$.

Table 1. Literature search strategy

\begin{tabular}{lccc}
\hline Search strategies & $\begin{array}{c}\text { Number of quotes per searched } \\
\text { database } \\
\text { Pubmed }\end{array}$ & Scielo \\
\hline $\begin{array}{l}\text { Strategy 1 - "Chronic pain" + } \\
\text { "Medicine in art" }\end{array}$ & 0 & 5 & \\
$\begin{array}{l}\text { Strategy 2 - "Chronic pain" + } \\
\text { "Painting" }\end{array}$ & 0 & 1 & 0 \\
Strategy 3 - "Frida Kahlo"* & 8 & 20 & 11 \\
\hline
\end{tabular}

Note: *The term "Frida Kahlo", although not being a DeCS descriptor, was included to obtain a higher number of texts on the subject.

Six texts supporting current investigation were selected, according to inclusion criteria - approach of aspects related to Frida Kahlo's art, especially intersections with pain experience - so as to contemplate the objective proposed by the study. Other manuscripts - already known by the authors - have complemented the literature review. Articles were read and information was organized in different sections - (1) "The 'origins' of Frida", (2) "The First Accident", (3) "The Second Accident: Diego Rivera", (4) "The Martyrdom of Frustrated Motherhood" - which will be presented below.

\section{CONTENTS: LIFE, ART AND PAIN}

Frida's suffering expression through the art has represented different moments of her life. Although using painting to translate her anguish in face of the tragedies that have marked her existence, adversities along her way had not prevented her from being a dynamic woman, culturally and politically engaged, aspect which is roared on her paintings.

\section{The "origins" of Frida}

Initial aspects of Frida's trajectory of life are exposed in different paintings, especially in My birth (1932) and My nurse and I (1937) - respectively figures 1 and 2 -, where it is evident the delicate relation between the painter and her mother. Matilde Calderón y Gonzales, daughter of a photographer of Indian ancestry, was Christian and housewife. She had been engaged to a German who committed suicide in front of her to prove his love for her. The further union with Guillermo Kahlo, also of German origin, has probably not erased the memory of her first fiancé. He remained in her memory - and in different reports - as her great love ${ }^{1}$.
Guillermo Kahlo, trader of photographic articles, was born in Baden-Baden; professional photographer, he immigrated to Mexico when he was 19 years old. Having been considered the "first official photographer of Mexican cultural assets", Guillermo Kahlo is described as a refined man interested in philosophy. He has not established an affective relation with his daughters, except with Frida, with whom he was very affectionate. In addition, Mr. Kahlo deposited in Frida his expectations of a nice professional future, encouraging girl's intellectual development and spirit of adventure. She used to accompany him during his walks and amateur painter activities, in addition to being his confident. He also taught her to operate a camera, develop, retouch and color photographs, experiences which would be useful for her painter career.

Frida: Why have you married, papa?

Guillermo Kablo: Can't remember. To have you ${ }^{4}$.

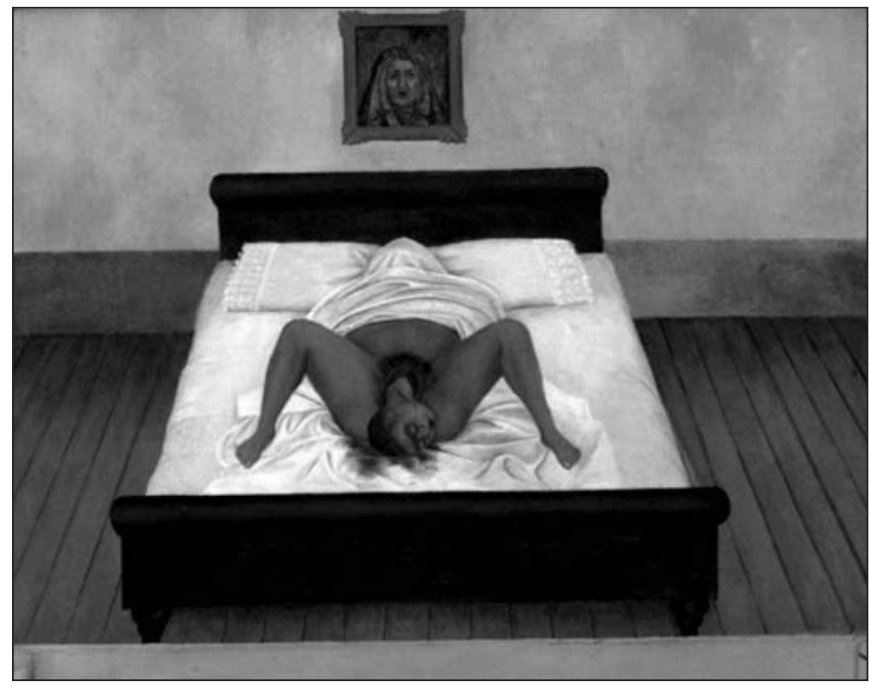

Figure 1. Mi nacimiento (My birth) - 1932. Oil on metal $30.5 \times 35 \mathrm{~cm}$. Private collection of "La Madonna". Consulted in http://www.fridakahlofans.com/c0100.htm

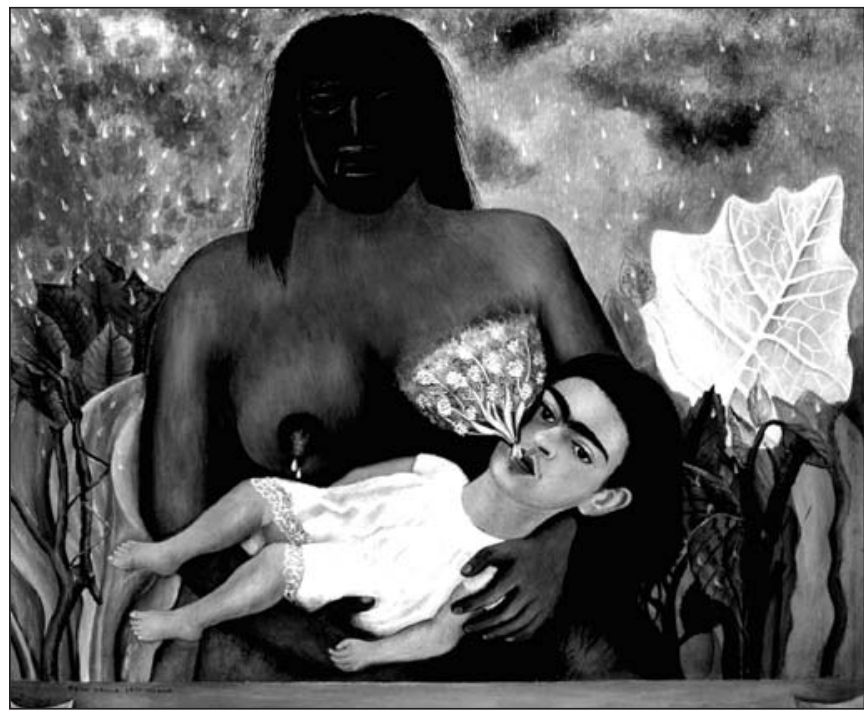

Figure 2. Mi nana y yo (My nurse and I) - 1937. Oil on metal 30,5×37cm. Dolores Olmedo Patiño Museum, Mexico City, Mexico. Consulted in http://www.fridakahlofans.com/c0190.html 
the care of an Indian wet-nurse. In figure 2, the stone mask of the nurse, as well as the lack of visual contact with the baby, reflect the distance between caregiver and the girl ${ }^{5}$.

It is supposed, in fact, that the absence of the mother, fact which is confirmed by the significant link of Frida with the father - may be as "compensation" - was also an encouraging and inspiring event for her artistic awakening 5 .

\section{The first accident}

Sequelae and disabilities resulting from the accident suffered when she was 18 years old were reproduced in different moments of her life.

Pain is an unpleasant sensation, however essential for survival. Physiologically, pain may be expression of any real or potential tissue injury ${ }^{6,7}$. Pain definition by the International Association for the Study of Pain (IASP) says that "pain is an unpleasant sensory and emotional experience expressed by the individual as representing a real or potential injury, or described in terms of such injury"s.

Sensory system for pain is broad. Because pain is an individual experience, it is understood that its perception varies according to the interference of several factors, such as ethnicity, gender and age, among others. In fact, pain experience is far reaching and its interpretation by individuals is multidimensional - acquiring different qualities and intensities - being expressed with different characteristics, established by affective-emotional, cultural, subjective and behavioral elements ${ }^{6,7}$. In a more comprehensive conception, it is admitted that pain is a symptom present in most diseases, be it as direct manifestation or being part of the diagnostic process and/ or therapy. In addition, illness produces a state of emotional pain, directly related to the awareness of human finitude and frailty ${ }^{7}$.

Guillermo Kablo: How do you feel Frida?

Frida: I don't even remember how it was before the pain ${ }^{4}$.

The reach of her suffering was expressed - in artistic terms - through exposed organs and bleeding bodies with scars? In the painting The broken column (1944) - figure 3 -, Frida expresses the severe pain she felt. In this painting, the artists portraits herself using a steel corset - which was indicated to control pain - with emphasis to her open body were a Ionic column is inserted broken in several places, symbolizing her damaged spine. Pain is present through nails pierced on her naked body, translating the endless martyrdom. Frida's body is divided, bleeding, pierced and isolated, thus showing the physical torture which has never left her throughout life "I don't even remember how it was before the pain". Solitude, represented by the desert scenario, reinforces the suffering of her condition. In the efforts to relieve her own pain, she has been submitted to several orthopedic surgeries - aiming at repairing the spine - both in Mexico and in the United States, without improving her complaints. The open body suggests the surgery ${ }^{10,11}$.

In the attempt to explain the reasons for her chronic pain, some authors suggest that Frida has suffered from post-trau-

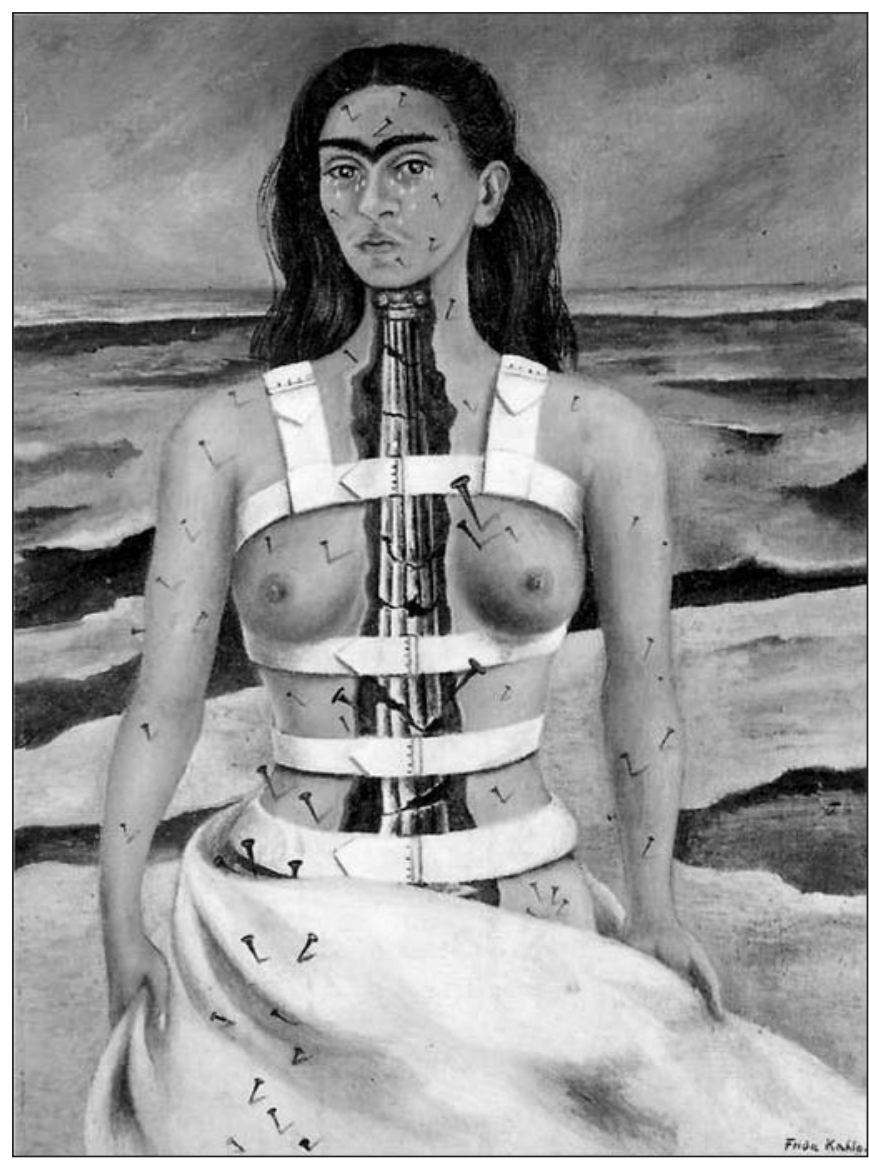

Figure 3. La columna rota (The broken column) - 1944. Oil on canvas mounted on hard fiber $43 \times 33 \mathrm{~cm}$. Dolores Olmedo Patiño Museum, Mexico City, Mexico. Consulted in http://www.fridakahlofans.com/ c0480.html

ma fibromyalgia, which is characterized by persistent generalized pain, chronic fatigue, sleep disorders and the presence of tender points in well-defined anatomic regions. This concept of fibromyalgia - such as it is currently understood - was possibly unknown by physicians of early $20^{\text {th }}$ Century. It has been also suggested that nails pierced on her body could represent typical fibromyalgia tender points - "trigger points". This hypothesis would explain her chronic pain and deep fatigue, as well as her poor therapeutic response ${ }^{11}$.

Physician: Since when is your foot like this?

Frida: Who knows. Let's go with one desgrace at a time. Plaster me so that I can paint.

Physician: This is gangrene. I will have to amputate it. Lucky you that the leg is spared'.

\section{The "second accident": Diego Rivera}

The artistic identification and the Mexican and communist ideals of Frida and Diego are probably among the ingredients of the intense and troublesome relationship lived by both, full of betrayals, hopelessness, pain and abandonment. Until the end of her life, Kahlo has unconditionally loved Rivera and, as a consequence, her suffering was so intense to the point 
of considering the romance as the "second accident" of her life. The marriage of Frida and Diego was marked by several vicissitudes, three spontaneous miscarriages and three major surgeries - portrayed in several paintings in different ways ${ }^{1}$. Several are the artworks expressing the anguish and suffering of dependence links cultivated by the artist, deserving special attention a canvas which stands out for the deep despair and delusion lived by the painter: The heart (Figure 4).

There, Frida illustrates a huge broken heart at her feet, expressing, it is believed, the intensity of her pain due to the romance of her husband with her sister Cristina. This fact has reinforced the rivalry between both, since the early birth of the youngest sister - as already mentioned -, led Frida to feel herself neglected, especially due to the breakage of maternal link between Frida and her mother ${ }^{5}$. It is equally important to comment that in this same painting Frida has short hair, a way to spite Diego. At her side there are her European-style clothes, making reference to the time when she was separated from Diego, who preferred dresses of the Tehuana tradition. Her left foot is over the water with an apparatus and, together, they look like a sailboat, making reference to a left foot suergery. Her school uniform at the background could be a representation of the time she met Diego, still a school girl.

Frida: With my sister? You animal!

Diego: I am a best, an idiot, but it didn't mean a thing. Nothing! Talk to me.

Frida: I had two tragic accidents in my life. The trolley car and you. And you were the worst ${ }^{4}$.

The painting The Two Fridas (Figure 5), in special, portraits very well the pain of separation. The canvas was painted after divorcing from Diego Rivera. Afterward, Frida has admitted that the painting was the reflex of her emotions about her separation and of her emotional crises. The artist has painted herself with two different personalities - through two opposite women - one represented by the Mexican Frida (to the right) - holding an amulet with the picture of Diego as a child - and an European Frida (to the left). These characters represent, respectively, the loved and respected woman by Rivera and the one rejected by the painter. In the painting, although just the rejected part is in danger of bleeding to death, exposed hearts of both, linked by a blood vessel, reflect the suffering generated by the end of her marriage ${ }^{12}$.

Similarly, love delusion is shown in Self-portrait with cropped hair (Figure 6).

Here, the painter is sitting on a chair surrounded by her long hair, which fills the emptiness representing the loving mismatch. The verse of a song - painted across the top - reflect the feeling of rejection by the loved man: "See, if I loved you, it was for your hair, now you're bald, I don't love you any more". In addition, the wide and dark man's suit, as opposed to female clothes which are distinct traits of the Mexican culture, always standing out on her self-portraits, expresses the resizing of her femininity, so deep was her suffering.

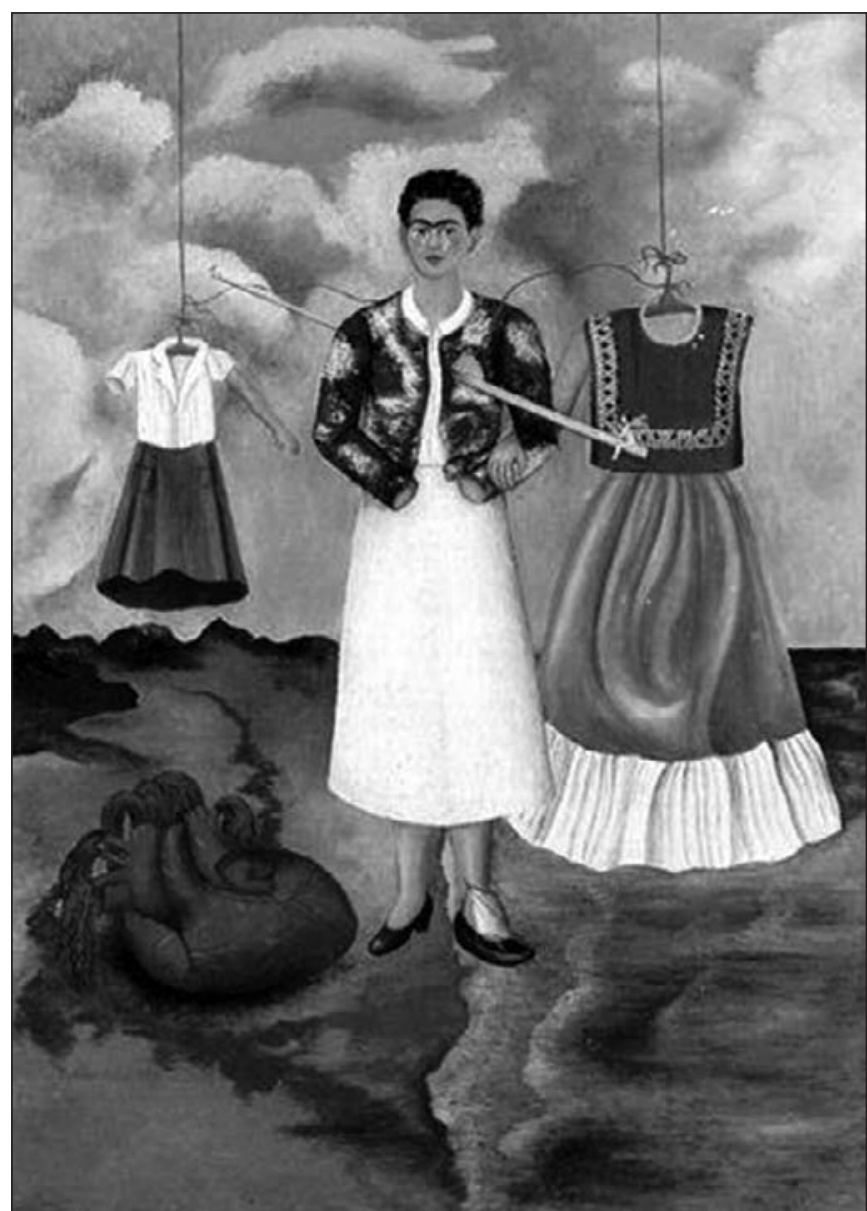

Figure 4. Recuerdo (El corazón) (The heart) - 1937. Oil on metal 40 x $28.3 \mathrm{~cm}$. Michel Petitjean Collection Paris, France. Consulted in http://www.fridakahlofans.com/c0180.html

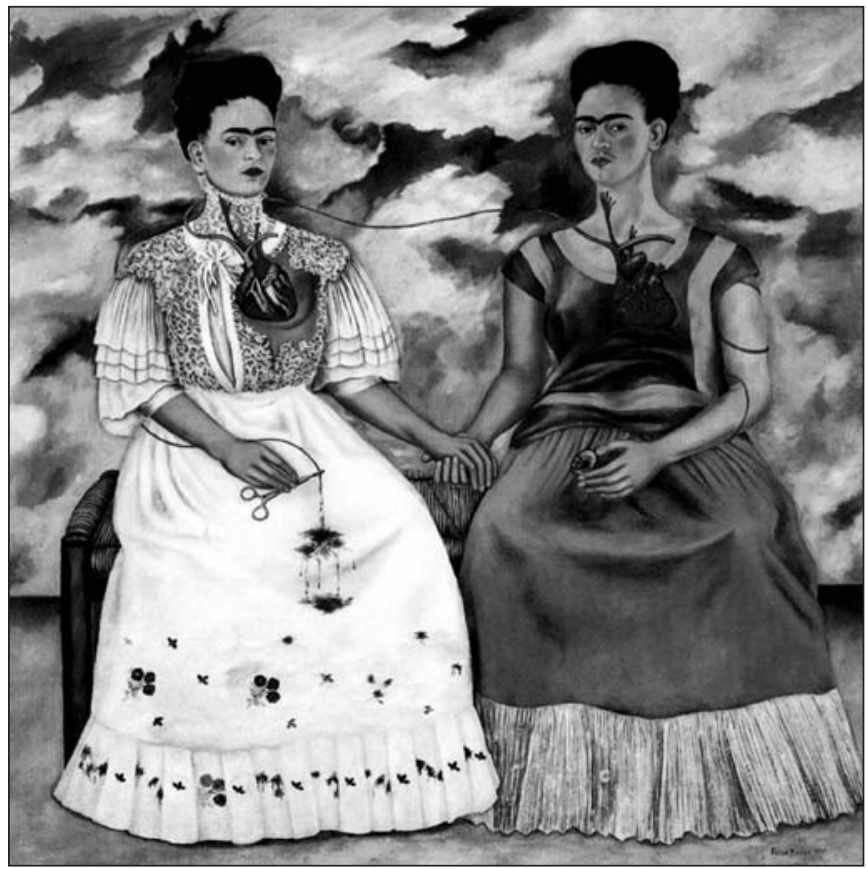

Figure 5. Las dos Fridas (The two Fridas) - 1939. Oil on canvas 173.5 x $173 \mathrm{~cm}$. Modern Art Museum, Mexico City, Mexico. Consulted in http://www.fridakahlofans.com/c0290.htm 


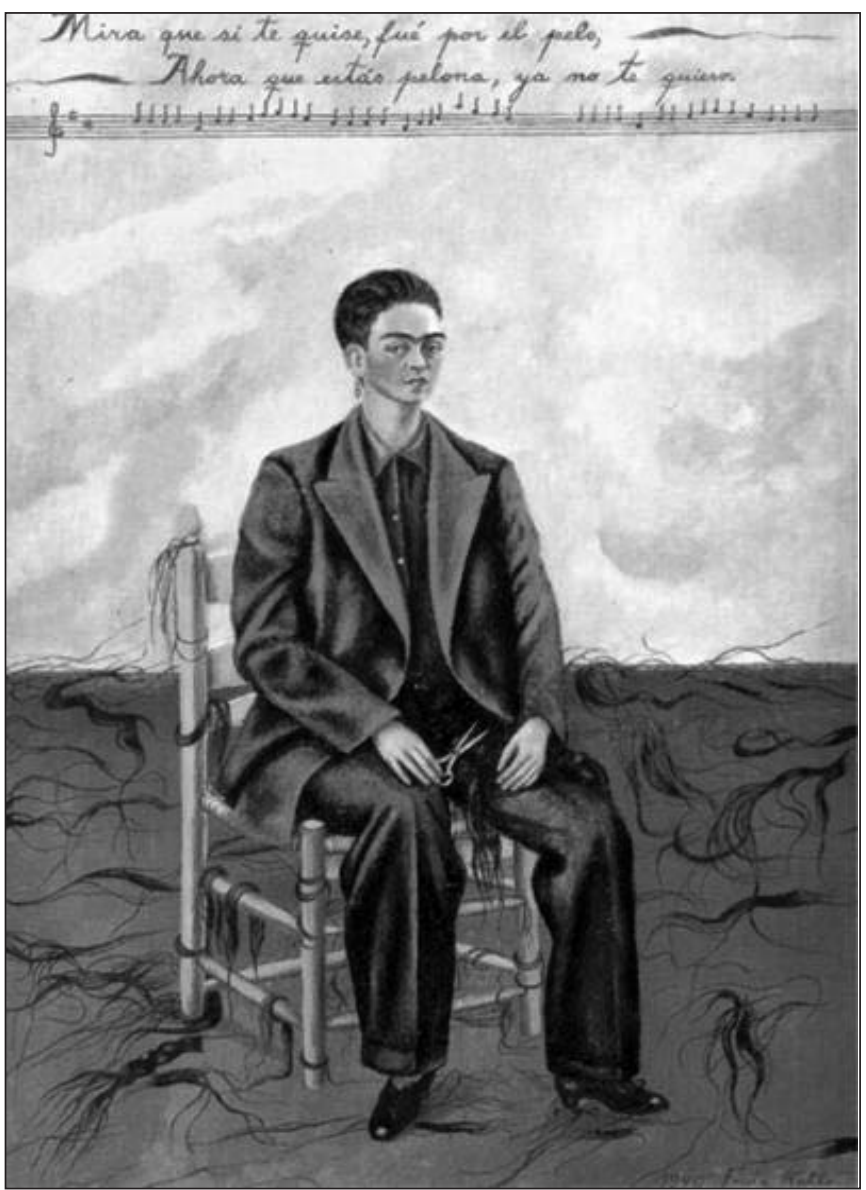

Figure 6. Autorretrato con pelo corto (Self-portrait with cropped hair) - 1940. Oil on canvas $40 \times 28 \mathrm{~cm}$. Museum of Modern Art of New York City, New York, USA. Donated by Edgar Kaufmann, Jr. Consulted in http://www.fridakahlofans.com/c0330.html

\section{The martyrdom of frustrated motherhood}

The impossibility of becoming a mother - a consequence of the pelvic fracture suffered in the accident - certainly was reason for deep grief, well illustrated by the Henry Ford Hospital painting (Figure 7) and by the dialog below (extracted from the movie Frida):

\section{Frida: I am pregnant.}

Diego: Would your body support?

Frida: He (physician) is not optimistic.

Diego: I would hate to see you suffering.

Frida: I am used to.

Diego: Do you really want to have this baby?

Frida: Yes.

Diego: Ok, let's try to have him.

Frida: Diego! The baby came out in pieces. I want to see my son ${ }^{4}$.

Here, Frida portraits the sorrow of the second miscarriage, through images full of symbolism. Around her there are six objects: an anatomic model of the pelvis, a fetus, a snail, an autoclave, an orchid and a bone pelvis. They are all connected by a red filament - possibly representing a blood vessel or an umbilical cord - which is held by the artist. The anatomic fe-

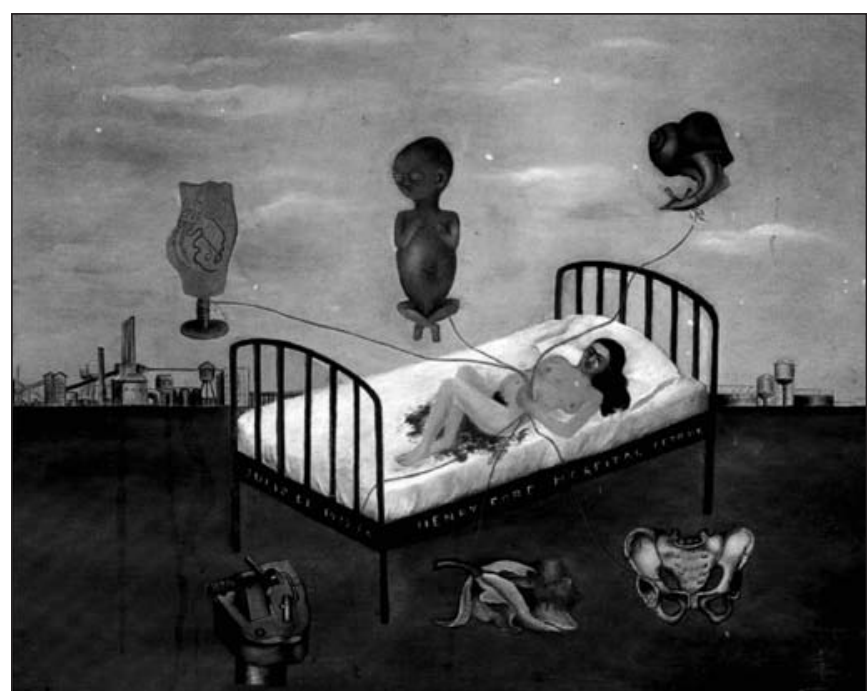

Figure 7. Henry Ford Hospital (La cama volando) (The flying bed) 1932. Oil on metal $30.5 \times 38 \mathrm{~cm}$. Dolores Olmedo Patiño Collection, Mexico City, Mexico. Consulted in http://www.fridakahlofans.com/ c0090.html

male pelvis model suggests the idea of the body as mere organs to be inspected and manipulated by physicians. The perfectly formed male fetus represents the new life she had longed to have. The snail alludes to the slow paced miscarriage. The autoclave represents her concern with the probability that the accident had made her sterile. The orchid, Diego's gift, may refer to external female genitalia, and the bone pelvis suggests the inherent human body frailty, as revealed by her accident. The conflict of frustrated motherhood is expressed by the human body ambivalence in her art. If on one side the body is a container for suffering, representing pain as a non-shared feeling, on the other hand, Frida artistically represents her body as a means of external projection and sharing of her suffering. This way, through the posture, expression and exteriorization of her internal anatomy, she is able to convey the whole complexity of her experience ${ }^{13}$.

\section{CONCLUSION}

Pain is expressed in different manners and its multiple shades may be identified in the culture, true attempts to give any sense to suffering. Life may be worth living provided subjects take over their desires to create, constituting directives and being really willing to learn how to live $\mathrm{e}^{14}$. In this sense, the art of Frida Kahlo intensively expresses a biography full of remarkable episodes.

Without using disguises or any other subterfuge, the artist paints legitimate life experiences, through which she has filled gaps - which existence has not filled or has filled with distressing situations - maybe as a way to translate the cruelty of pain. Although having her life characterized by severe physical and psychic suffering, this suffering was elaborated and symbolized by the artist using bright colors to cope with pain. Frida had in the art her major comfort, transforming and creating her painful trajectory in a work which has reflected her own feelings about her existence. 


\section{ARTWORKS}

Frida Kahlo Fans. Web page dedicated to the Mexican painter. Consulted in www.fridakahlofans.com, February 28, 2014. Paintings included in this article were consulted in this site. Frida Kahlo Museum. Consulted in http://www.museofridakahlo. org. $\mathrm{mx} /$, February 28, 2014.

\section{REFERENCES}

1. Bastos MM, Ribeiro MA. Frida Kahlo: uma vida. Psicanálise \& Barroco. 2007;5(2):46-76.

2. Orsini M, De Freitas MR, Coin CL, Mello MP, Catharino MA, Vaz AC, et al. Frida Kahlo: A arte como desafio à deficiência e à dor, com enfoque na poliomielite anterior aguda. Rev Bras Neurol. 2008;44(3):5-12.

3. Levinzon GK. Frida Kahlo: a pintura como processo de busca de si mesmo. Rev Bras Psicanal. 2009;43(2):49-60.
4. Frida. EUA / Canadá: Miramax Films / Trimark Pictures, 2003.

5. Outeiral J. Meros Ensaios: Escritos Psicanalíticos. Editora Revinter: Rio de Janeiro, 1999.

6. Silva JA, Ribeiro-Filho NP. A dor como um problema psicofísico. Rev Dor. 2011;12(2):138-51.

7. Canguilhem G. Escritos sobre a medicina. São Paulo: Forinse; 2005.

8. Pain terms: a list with definitions and notes on usage. Recommended by the IASP Subcommittee on Taxonomy. Pain. 1979;6(3):249.

9. Kelner G, Boxwell S, Silva AR. Catástrofe e representação na pintura de Frida Kahlo. Pulsional Rev Psicanál. 2000;XIII(132):34-44.

10. Lomas D, Howell R. Medical imagery in the art of Frida Kahlo. BMJ. 1989;299(6715):1584-7.

11. Martínez-Lavín M, Amigo MC, Coindreau J, Canoso J. Fibromyalgia in Frida Kahlo's life and art. Arthritis Rheum. 2000;43(3):708-9.

12. Fernandes FS. O mapa íntimo: três telas de Frida Kahlo. Rev Estud Fem. 2008;16(1):35-44.

13. Gunderman RB, Hawkins CM. The self-portraits of Frida Kahlo. Radiology. 2008;247(2):303-6.

14. Siqueira-Batista R, Batista RS, Schramm FR. 'O sétimo selo' de Bergman e 'O estrangeiro’ de Camus: os matizes da finitude. Existência e Arte. 2010;5:1-10. 